American Journal of Animal and Veterinary Sciences 5 (3): 187-191, 2010

ISSN 1557-4555

(C) 2010 Science Publications

\title{
Osmolarity of Coconut Water (Cocos nucifera) Based Diluents and their Effect Over Viability of Frozen Boar Semen
}

\author{
Bottini Luzardo, M. Centurion Castro, F. Alfaro Gamboa, \\ M. Alzina Lopez and A.Y.R. Ake Lopez \\ Department of Reproduction, Faculty of Veterinary Medicine and Animal Sciences, \\ UADY, Km 15.5 Carr, Merida-Xmatkuil, Ap. Postal 4-116 Itzimna, \\ Merida, Yucatan, Mexico
}

\begin{abstract}
Problem statement: Boar sperm cells are sensitive to the freezing process, which compromises viability of frozen-thawed sperm. In a constant search for minimizing or suppressing sperm cell damage caused by the temperature and osmolarity changes during the freezing process, crioprotective and antioxidant substances have been added to the freezing media, such as coconut water, in order to increase the viability of frozen-thawed swine semen. The addition of any substance to the freezing diluent, directly affects osmolarity of the media, which can have positive or negative effects over the sperm cell. Approach: There are no published studies currently that indicate the effect of adding coconut water over the osmolarity of freezing media and their effect over viability of sperm cells, therefore, the objective of the present study was to evaluate the effect of coconut water based diluents osmolarity over the Motility (Mot), Acrosome Integrity (AI), Membrane Integrity (MI) and Mitochondrial Activity (MA) of thawed boar sperm cells. The treatments used were control T1 (LEY with bidistilled water + LEYGO) with an osmolarity range of 296-368 mOsmol $\mathrm{Kg}^{-1}$, T2 (LEY and deionized coconut water + LEYGO) between 381 and $480 \mathrm{mOsmol} \mathrm{Kg}^{-1}$ and T3 (LEY and in natura coconut water + LEYGO) between 519 and $1041 \mathrm{mOsmol} \mathrm{Kg}{ }^{-1}$. The Westendorf modified method was the freezing method used. The obtained data were statistically analyzed by GLM, using the SAS software (SAS, 2000). Results: A significant difference was observed on T2 compared to T1 regarding Mot 41.9 Vs $36.9 \%$ and MI 58.0 Vs 50.2. T3 had a detrimental effect on all studied variables. Conclusion: Under our study conditions, the osmolarity range of $\mathrm{T} 2$, due to the non ionic solutes content, contributed to improve the viability of frozen-thawed sperm cells.
\end{abstract}

Key words: Coconut water, osmolarity, boars sperm, freezing media, Cocos nucifera

\section{INTRODUCTION}

Among the different strategies to increase animal production in swine herds, the creation of genetically superior strands with a great productive-reproductive potential is a very important one. In the case of boars, a way to preserve this genetic material and make it accessible to other swine farms is through the use of refrigerated or frozen semen. This one is easier to transport and to keep for longer time periods without posing a biosecurity hazard to other swine populations. However, the damages caused to the swine sperm cells due to the changes in temperature and osmolarity during the freezing process can decrease fertility and consequently affects prolificacy. These consequences have limited the use of frozen boar semen at a large scale and restricting it to genetic centers, wasting thus the important advantages that frozen semen can offer. In a constant search to minimize or suppress damages caused by criopreservation, several crioprotective and antioxidant substances have been added to the freezing media in order to increase the frozen-thawed swine semen viability. Since many decades ago, several studies have added coconut water (Cocos nucifera) to the refrigeration and freezing media in sheep, swine and bees (Kotzias-Bandeira et al., 1999; Almeida and Soares, 2002; Gutierrez et al., 2006; Nejat et al., 2009) to take advantage of the nutrients, crioprotectors and antioxidants that coconut water provides and to improve sperm viability. However, other studies report detrimental effects over frozen-thawed sperm viability when adding coconut water to the freezing media (Santillana Bonet and

Corresponding Author: M. Centurion Castro, Department of Reproduction, Faculty of Veterinary Medicine and Animal Sciences, UADY, Km. 15.5 Carretera Merida-Xmatkuil, Apdo, Postal 4-116 Itzimna, Merida, Yucatan, Mexico Tel: +52 (999) 9423200 Fax: +52 (999) 9423205 
Garcia Garcia, 2000; Gutierrez et al., 2006), possibly as a consequence of the osmolarity change in the freezing media. It is important to recall that the addition of any substance to the freezing diluents affects directly the osmolarity, bringing positive or negative effects over the sperm cell. It is necessary then to evaluate the osmolarity of diluents after adding any substance and to verify these osmolarity ranks are within those tolerable by the sperm cell. Up to the present, the effect of adding coconut water over the diluents osmolarity and their effect over the sperm cell have not been studied. The objective of the present study was to evaluate the osmolarity of coconut water based diluents and their effect over the frozen boar semen viability.

\section{MATERIALS AND METHODS}

The present study was performed from September to November 2010 at the Veterinary and Animal Husbandry School of the Autonomous University of Yucatan. The climate of the region is AW0 warm, subhumid with summer rains. The average annual temperature is of $27.7^{\circ} \mathrm{C}$, relative humidity reaches $80 \%$ and the annual mean precipitation is of $800 \mathrm{~mm}$.

Coconut fruits (Cocos nucifera L. Mexican Pacific tall 2 var.) of an approximate age of 9 years, obtained from an experimental field in San Crisanto County, property of the Yucatan Scientific Research Center (CICY) were used.

The coconuts were taken to the lab and the water was extracted to determine the calcium content using the permanganate method (Water Pollution Control Federation, 1992). The calcium content of the coconut water was of $1.82 \times 10^{-2} \mathrm{M}$.

Once calcium concentration was determined, part of the coconut water went under a deionization process in order to eliminate the excess calcium. The other part of the coconut water was filtered to eliminate suspended particles. The coconut water to be deionized, was extracted in sterile conditions under a bilaminar flow hood and deionized using a (BARNSTEAD D0803, USA) electric deionizer, obtaining a final $\mathrm{Ca}^{2+}$ concentration of $0 \mathrm{M}$.

The filtration process was done under sterile conditions by placing the coconut water in a container with a capacity of $1 \mathrm{~L}$ container and placing in another container of the same capacity a \# 40 filter study. The final $\mathrm{Ca}^{2+}$ concentration was of $1.82 \times 10^{-2} \mathrm{M}$.

A sample of about $15 \mathrm{ml}$ of deionized and filtered water was taken to measure $\mathrm{pH}$ and osmolarity, making the necessary adjustments. Posterior, samples were kept at $5^{\circ} \mathrm{C}$. The $\mathrm{pH}$ values were obtained using a CORNING
7 potentiometer and osmolarity was obtained using an automatic Osmometer (OSMOTTE A 5002). The adjustment of $\mathrm{pH}$ was done using a $2.9 \%$ sodium citrate solution. Deionized coconut water had osmolarity values between 68-117 mOsmol k $\mathrm{k}^{-1}$, whereas filtered coconut water vales were of $240-310 \mathrm{mOsmol} \mathrm{kg}^{-1}$.

Three diluents (treatments) were prepared: Treament 1 LEY (bidistilled water, lactose and egg yolk) and LEYGO (LEY + glycerol and orvus ES paste) which was used as control; Treatment 2 (Grobfel et al., 2008) LEY $_{\mathrm{A}}$ (deionized coconut water, lactose and egg yolk) and $\mathrm{LEYGO}_{\mathrm{A}}\left(\mathrm{LEY}_{\mathrm{A}}+\right.$ glycerol and orvus ES paste $)$ and Treatment $3 \mathrm{LEY}_{\mathrm{B}}$ (filtered coconut water, lactose and egg yolk) and $\mathrm{LEYGO}_{\mathrm{B}}\left(\mathrm{LEY}_{\mathrm{B}}+\right.$ glycerol and orvus $\mathrm{ES}$ paste). The volume prepared for each treatment depended on the sperm cells concentration by ejaculation.

The osmolarity of the LEY diluents prepared for each treatment was determined taking two $2 \mathrm{~mL}$ aliquots. The diluents osmolarity was the mean of the osmolarity of these two aliquots. Osmolarity was determined in each freezing process accounting for a total of 22 measurements. T1 had osmolarity values ranged from 296-380 mOsm kg-1, T2 ranged from 381-480 mOsm $\mathrm{kg}^{-1}$ and $\mathrm{T} 3$ ranged from 519-1041 $\mathrm{mOsm} \mathrm{kg}^{-1}$.

Six boars from the PIC line between 2 and 4 years of age were used. These boars were frequently used as widgets and were considered as good freezers based on the quality of their semen after freezing ( $\geq 40 \%$ motility) in three occasions. All boars were kept under the same management and feeding regimen. A total of 22 collections were done using vinyl gloves. Only the rich fraction (Corcuera et al., 2007) was used. The semen collecting was done at 7 day intervals for every boar.

Semen samples obtained were immediately put in a water bath at $37^{\circ} \mathrm{C}$ and general assessment was done, determining mainly the sperm motility, which was done in two ways; first, masal motility and then individual motility, following the Zemjanis (1962) procedure.

Once the sample was considered suitable for freezing by presenting less than 3.5 crosses on masal motility and $80 \%$ of individual motility (Caballero et al., 2004; Satorre et al., 2007), freezing was made place, following the method pointed by Sellos (2001). For the freezing process, in all treatments, it was considered to add the corresponding LEY volume for reaching a final concentration of 1500 million sperm cells $\mathrm{mL}^{-1}$. After diluting with LEY, the semen of each sample was chilled for $2 \mathrm{~h}$ at $5^{\circ} \mathrm{C}$; upon this period, LEYGO diluent was added until reaching a final concentration of 1000 million sperm cells $\mathrm{mL}$. 
Before packaging semen, motility was evaluated andonly samples that had at least $85 \%$ of individual sperm motility were used. Straws of $0.54 \mathrm{~mL}$ were filled and an automatically filled with a packing unit (Foruard, France). Each straw contained 500 million sperm cells. Straws were placed over a steel base and were exposed for $20 \mathrm{~min}$ to the nitrogen vapors. Afterwards, they were directly submerged in liquid nitrogen and were kept at $-196^{\circ} \mathrm{C}$ until their evaluation.

Evaluation of the seminal characteristics was done taking five straws by treatment and thawing them in a water bath at $38^{\circ} \mathrm{C}$ for $20 \mathrm{sec}$, the content of each straw was poured in vials with $0.5 \mathrm{~mL}$ BTS and the postfreezing evaluation was done $5 \mathrm{~min}$ after thawing. Frozen-thawed semen viability was determined using 4 seminal parameters: Individual Motility (Mot) which was evaluated in a percentage scale of 0-100 using the same afore mentioned methodology (Zemjanis, 1962). Acrosome Integrity (AI), this indicator was evaluated according to Grobfel et al. (2008) and Zulkifli et al. (2010). Membrane Integrity (MI) was evaluated using fluorochrome and propidium iodide (Chaiprasert and Vitidsant, 2009) and observing through an epifluorescent microscope (Olympus, Japan) at $1000 \mathrm{X}$. Mitochondrial activity (MA) was evaluated using the fluorescence technique using Rhodamine 123 (Alhaidary et al., 2010). The sample was observed through an epifluorescence microscope at 1000X.

A random block design was used, where independent variables were the osmolarity of the three diluents, the response variables were individual motility, membrane integrity, acrosome integrity and mitochondrial activity. Prior to analyzing the values of the dependent variables, these were transformed to the arc sin. The responses were analyzed using a general linear model. The means of treatments that showed significant differences were analyzed using the LSD test to identify those treatments that were different. Differences were considered significant when the $p$ value was less than 0.05 . The software used was Statistical Analysis Systems Version 8.1, (Institute, Cary, North Carolina).

\section{RESULTS}

The diluents osmolarity had effects over all sperm viability indicators (Table 1). Regarding sperm motility percentage, treatment 2 (deionized coconut water) obtained the highest results $(\mathrm{p}<0.05)$, compared to treatment 1 (control and) T3 (filtered coconut water). $\mathrm{T} 3$ yielded the lowest motility percentages $(\mathrm{p}<0.05)$.

When evaluating acrosome integrity, membrane integrity and mitochondrial activity, no significant differences were observed between $\mathrm{T} 1$ and $\mathrm{T} 2(\mathrm{p}<0.05)$, whereas T3 showed the lowest values, being significantly different to $\mathrm{T} 1$ and $\mathrm{T} 2(\mathrm{p}<0.05)$.
Table 1: Effect of the freezing diluent's osmolarity over motility, acrosome integrity, membrane integrity and mitochondrial activity of frozen-twawed swine semen (means $\pm \mathrm{SE})^{\mathrm{a}}$

\begin{tabular}{lllll}
\hline Treatment & Motility $(\%)$ & $\begin{array}{l}\text { Acrosome } \\
\text { integrity }(\%)\end{array}$ & $\begin{array}{l}\text { Membrane } \\
\text { integrity }(\%)\end{array}$ & $\begin{array}{l}\text { Mitochondrial } \\
\text { activity }(\%)\end{array}$ \\
\hline T1 & $36.85^{*} \pm 1.86$ & $60.92 \pm 2.23$ & $51.39 \pm 1.46$ & $56.64 \pm 1.66$ \\
T2 & $41.42 * * \pm 1.74$ & $61.86 \pm 2.50$ & $55.26 \pm 1.78$ & $60.61 \pm 1.95$ \\
T3 & $6.39 * * * \pm 1.09$ & $38.67 * \pm 3.54$ & $41.57 * \pm 1.50$ & $50.85 * \pm 2.36$ \\
\hline
\end{tabular}

a Different number of asterisks $\left(^{*}\right)$ in a same column indicate significant differences $(\mathrm{p}<0.05)$

\section{DISCUSSION}

The diluent osmolarity is an important feature that must be considered to achieve good results in the semen freezing process of any species.

The studies performed with boar semen suggest there is a higher amount of viable post-frozen sperm cells when the freezing media is slightly hypertonic (420-510 mOsm $\mathrm{kg}^{-1}$ ) (Zheng et al., 2001). It was observed in the present study that freezing diluents used showed osmolarities that differed from isotonic 296$380 \mathrm{mOsmol} \mathrm{kg} \mathrm{kg}^{-1}$ in $\mathrm{T} 1$, slightly hypertonic $381-480$ mOsmol kg-1 in T2, up to hypertonic values 519-1041 mOsmol kg ${ }^{-1}$ in T3, being these osmolarities a direct consequence of each diluents' components.

The osmolarity of the freezing media had a significant effect over the frozen-thawed semen evaluated characteristics. Table 1 shows the highest individual motility values, acrosomal integrity, membrane integrity and mitochondrial activity were obtained when the diluents had osmolarities between 381 and $480 \mathrm{mOsm} \mathrm{kg}^{-1}$ (T2) andthe lowest values were obtained when the osmolarity was equal or higher than 519 mOsm kg$~^{-1}$ (T3). These results agree with those reported by Zheng et al. (2001), who pointed out the highest motility percentage, acrosome and membrane integrity in swine semen were obtained with diluents that had osmolarities between 420 and 510 mOsm $\mathrm{kg}^{-1}$. Similarly, the results also agree with those reported by Gilmore et al. (1996) and Yunus et al. (2009), who explain that motility, membrane integrity and acrosome integrity percentage follow a positive linear response with osmolarities that range from isotonic to slightly hypertonic, which were obtained with $\mathrm{T} 1$ and $\mathrm{T} 2$ in the present study. The very same osmolarity ranges (425 to $525 \mathrm{mOsmo} \mathrm{\textrm {kg } ^ { - 1 }}$ ) are pointed out by Purdy (2006) as ideal for sheep semen freezing, stating that osmolarity values above $525 \mathrm{mOsmol} \mathrm{kg}{ }^{-1}$ are harmful for frozen-thawed sheep semen viability.

The best results of sperm viability observed in $\mathrm{T} 2$ as compared to T3 were possibly due to the low osmolarity that deionized coconut water had, which only contained sugars, vitamins and antioxidants, that could have helped maintain the sperm's viability. On 
the other hand, the hypertonic feature of T3 could have been caused by the addition of filtered coconut water that had a high osmolarity as a consequence of the elevated concentration of $\mathrm{Ca}^{2+}$, among other ions, causing probably more damage at plasma membrane level than when hypertonic features were the result of non ionic solutes (sugars). Similar results were obtained by Zheng et al. (2001) and Yunus et al. (2009) in frozen-thawed swine semen subjected to hyperosmotic solutions due to $\mathrm{NaCl}$ ions and hyperosmotic solutions due to glucose, obtaining in the later up to $70 \%$ of viable sperm cells and $65 \%$ of intact acrosomes. In this sense, Soylu et al. (2007), who worked with frozen sheep semen, say that the addition of sugars to the freezing media until reaching an osmolarity of 400 mOsmol kg-1 allows to obtaining a higher percentage of motile sperm cells with untouched membranes after freezing.

\section{CONCLUSION}

The results obtained from the present study suggest the slight hyperosmolarity that confers the coconut water to the freezing diluent contribute to improve the frozen-thawed sperm viability. On the other hand, filtered coconut water added to the freezing media increases osmolarity of freezing media above levels tolerated by the sperm cell decreasing the frozenthawed swine semen quality. It is necessary then to decrease the coconut water's osmolarity to levels below $200 \mathrm{mOsmol} \mathrm{kg}{ }^{-1}$ prior to adding it to the freezing diluent to avoid frozen-thawed swine semen damage.

\section{AKNOWLEDGEMENT}

The researchers would like to thank the Produce Yucatan Fund, for the financing granted and the Scientific Research Center of Yucatan CICY for providing the coconut fruits used in the present study.

\section{REFERENCES}

Almeida, R. and A.E.E. Soares, 2002. Usage of green coconut water and different tissue culture media for in vitro honey bee semen storage (Apis mellifera Hymenoptera: apoidea). Interciencia, 27: 317-321. http://www.interciencia.org/v27_06/almeida.pdf

Alhaidary, A., H.E. Mohamed and A.C. Beynen, 2010. Impact of dietary fat type and amount on growth performance and serum cholesterol in rabbits. Am. J. Anim. Vet. Sci., 5: 60-64. http://www.scipub.org/fulltext/AJAV/AJAV516064
Caballero, I., J.M. Vazquez, F. Centurion, H. RodriguezMartinez and I. Parrilla et al., 2004. Comparative effects of autologous seminal plasma on the viability of largely extended boar spermatozoa. Reprod. Domest. Anim., 39: 370-375. DOI: 10.1111/j.1439-0531.2004.00530.x

Chaiprasert, P. and T. Vitidsant, 2009. Promotion of coconut shell gasification by steam reforming on nickel-dolomite. Am. J. Applied Sci., 6: 332-336. http://www.scipub.org/fulltext/ajas/ajas62332-336

Corcuera, B.D., P. Marigorta, A. Sagues, F. SaizCidoncha and J. Perez-Gutiérrez, 2007. Effect of lactose and glycerol on the motility, normal apical ridge, chromatin condensation and chromatin stability of frozen boar spermatozoa. Theriogenology, 67: 1150-1157. DOI: 10.1016/j.theriogenology.2007.01.002

Gilmore, J.A., J. Du, J. Tao, A.T. Peter and J.K. Critser, 1996. Osmotic properties of boar spermatozoa and their relevance to cryopreservation. J. Reprod. Fertil., 107: 87-95. DOI: 10.1530/jrf.0.1070087

Grobfel, R., B. Sieg, C. Struckmann, A. Frenzel and W.M.C. Maxwell et al., 2008. New aspects of boar semen freezing strategies. Theriogenology, 70: 1225-1233. DOI: 10.1016/j.theriogenology.2008.07.017

Gutierrez, A.J., M.M. Palacios, C.J.A. Jimenez and G.J.A. Ramirez, 2006. Coconut milk, Opuntia sp., milk and their combinations for cryopreservation of ovine semen. Arch. Zootec., 55: 97-100. http://www.uco.es/organiza/servicios/publica/az/ph p/img/web/09_20_00_12NotaAguaOpuntiaGutierr ez.pdf

Kotzias-Bandeira, E., D. Waberski, K.F. Weitze and M.B.P. Barreto, 1999. Pre-dilution and freezing of swine semen in natural coconut water at three different incubation pre-treatments. Braz. J. Vet. Res. Anim. Sci., 36: 1-10. DOI: 10.1590/S141395961999000300008

Nejat, N., K. Sijam, S.N.A. Abdullah, G. Vadamalai and M. Dickinson, 2009. Molecular characterization of a phytoplasma associated with Coconut Yellow Decline (CYD) in Malaysia. Am. J. Applied Sci., 6: 1331-1340. http://www.scipub.org/fulltext/ajas/ajas6713311340.pdf

Purdy, P.H., 2006. A review on goat sperm cryopreservation. Small. Rumin. Res., 63: 215-225. DOI: 10.1016/j.smallrumres.2005.02.015

Santillana Bonet, A. and A. Garcia Garcia, 2000. Comparative study of two diluents for freezing Pelibuey sheep semen. Puebla. http://www.exopol.com/seoc/docs/vzq5536o.pdf 
Satorre, M.M., E. Breininger, M.T. Beconi and N.B. Beorlegui, 2007. $\alpha$-tocopherol modifies tyrosine phosphorylation and capacitation-like state cryopreserved swine sperm. Theriogenology, 68: 7958-965.

DOI: 10.1016/j.theriogenology.2007.06.021

Sellos, E., 2001. Factors affecting quality and fertilizing capacity of criopreserved swine semen. UAC.

Soylu, M.K., Z. Nur, B. Ustuner, I. Dogan and H. Sagirkaya et al., 2007. Effects of various cryoprotective agents and extender osmolality on post-thawed ram semen. Bull. Vet. Inst. Pulawy, 51: 241-246.

http://bulletin.piwet.pulawy.pl/archive/512/11_soylu.pdf

Yunus, W.M.M., Y.W. Fen and L.M. Yee, 2009. Refractive index and Fourier transform infrared spectra of virgin coconut oil and virgin olive oil. Am. J. Applied Sci., 6: 328-331. http://www.scipub.org/fulltext/ajas/ajas62328-

331.pdf
Zemjanis, R., 1962. Diagnostic and Therapeutic Technique in Animal Reproduction. 1st Edn., Williams and Wilkins, USA., pp: 238.

Zheng, W.X., M. Shimada, N. Isobe and T. Terada, 2001. Survival of boar spermatozoa frozen in diluents of varying osmolality. Theriogenology, 56: 447-458.

http://www.theriojournal.com/article/S0093691X(01)00576-3/abstract

Zulkifli, R., M. Zulkarnain and M.J. Mohd Nor, 2010. Noise control using coconut coir fiber sound absorber with porous layer backing and perforated panel. Am. J. Applied Sci., 7: 260-264. http://www.scipub.org/fulltext/ajas/ajas72260-

264.pdf 